\title{
THEORITICAL REVIEW: TEORI MEREK HALAL
}

\author{
Oleh: \\ Yulfan Arif Nurohman \\ Dosen Tetap IAIN Surakarta
}

\begin{abstract}
The phenomenon of Islamic marketing and branding as a new and separate discipline has attracted the attention of both academics and practitioners. There is such confusion and improper use of the term of Islamic or Halal branding and until now there seems to be no clear understanding of what the term Halal branding means. For Muslims, branding cannot be separated from faith, which dictates that all actions should be divine and that one loves and hates not because of his humanly desires but because his feelings are in line with Allah's guidance. Additionally, significantly in promoting and improving the Islamic brands to the consumers, producers or marketers need to follow all the requirements that required by authorization bodies either in organization's practices and branding features to obtain consumer's trust and confidence upon Islamic branding. The Halal market, i.e. products that are Shariah-compliant represents a significant portion of Indonesia's economies. Developments in the growing field of Islamic marketing raise scholarly interest into its foundational principles and the many directions the field is taking.
\end{abstract}

Keyword: halal, islamic brand, halal clusters, halal brand image

\section{PENDAHULUAN}

Fenomena pemasaran dan branding Islam sebagai disiplin baru dan terpisah telah menarik perhatian akademisi dan praktisi baik dari dalam dan luar dunia Muslim. Pemasaran Islam menargetkan konsumen Muslim, konsumen yang berbeda secara khas dari konsumen pada umumnya dan memanfaatkan sumber daya, keterampilan dan alat khusus yang relevan dan menarik bagi segmen khusus ini (Sandikci, 2011). Perubahan demografi dan daya beli konsumen Muslim dan keberhasilan pengusaha Muslim telah mulai menjadikan pemasaran Islam sebagai bidang yang menarik secara ilmiah dan ahli (Sandikci, 2011). Oleh karena itu, praktik pencitraan merek Islam karena strategi pemasaran telah mendapatkan momentum yang cukup besar di kalangan akademisi dalam beberapa tahun terakhir, baik di dalam maupun di luar dunia Islam, (Alserhan, 2010) 
Merek agama Islam, atau merek halal, dibuat sesuai dengan prinsip-prinsip Islam yang membimbing apa yang diijinkan tidak hanya di industri makanan tetapi juga di bidang kosmetik, farmasi, logistik, pakaian, keuangan, perhotelan dan perbankan (Minkus-McKenna, 2007).

Industri halal mencakup tiga kategori utama:

1. Makanan yang saat ini didominasi oleh perusahaan multinasional non-Muslim seperti Kentucky Fried Chicken dan Nestle;

2. Gaya hidup, yang didominasi oleh perusahaan multinasional non-Muslim; dan

3. Layanan, termasuk keuangan, perhotelan, dan logistik antara lain.

Bagi umat Islam, branding tidak dapat dipisahkan dari iman, yang menentukan bahwa semua tindakan harus bersifat ilahi dan bahwa seseorang mencintai dan membenci bukan karena keinginan manusiawi namun karena perasaannya sejalan dengan tuntunan Allah. Hubungan dagang misalnya, meski menghasilkan kepuasan akan keinginan duniawi, mereka harus ditempa dengan maksud ilahi antara pihak bisnis. Oleh karena itu, keseluruhan hubungan tidak lagi bersifat materialistis dan berubah menjadi perbuatan baik yang akan dicatat dalam catatan ilahi masing-masing individu.

Islam bukan hanya tentang Halal dan Haram, seperti yang biasa dipahami oleh para ahli branding Muslim dan non-Muslim yang tidak berpengalaman dalam ajaran Islam yang terkait atau melihatnya dari perspektif abstrak, yaitu Halal dan Haram. Selain itu, banyak dari para ahli tersebut gagal untuk menghargai fakta dasar Islam bahwa Halal adalah norma dan Haram adalah pengecualian, yang secara harfiah berarti bahwa sebagian besar hal yang Allah ciptakan dan ajarkan kepada orang-orang tentang diciptakan Halal; Itulah yang dilakukan orang itu sendiri yang mengubahnya menjadi Haram. Sebagai ilustrasi, buah anggur diperintahkan di dalam Quran sebagai buah dari surga. Namun, mengolahnya menjadi minuman yang memabukkan membuat mereka haram. Internet adalah halal namun menggunakannya untuk menukar atau menyebarkan pornografi dan kebencian adalah Haram. 


\section{PENGERTIAN MEREK HALAL}

Merek sangat terkait dengan emosi, terlebih lagi ketika agama terlibat; Perbedaan semacam itu menjadi penting bagi perusahaan di pasar Islam memahami implikasi religius. Dari Wilson (2012), merek diciptakan dengan niat oleh pemiliknya sehingga dorongan konsumsi akan terjadi. Merek (brand) berfungsi mengidentifikasi barang atau jasa dari seorang atau sekelompok penyaji dan membedakannya dari produk sejenis dari penyaji lain (Kotler, 2000:163). Lebih dari itu, merek adalah sesuatu yang dibentuk dalam pikiran pelanggan dan memiliki kekuatan membentuk kepercayaan pelanggan (Peter \& Olson, 1996:168). Jika perusahaan mampu membangun merek yang kuat di pikiran pelanggan melalui strategi pemasaran yang tepat, perusahaan akan mampu membangun mereknya. Dengan demikian merek dapat memberi nilai tambah pada nilai yang ditawarkan oleh produk kepada pelanggannya yang dinyatakan sebagai merek yang memiliki ekuitas merek (Aaker, 1991:14).

Pemahaman tentang apa itu merek Halal dan Islam sangat penting dan jika konsumen Muslim tidak mendorong dan memelihara, merek-merek Islam akan tetap ada karena produk budaya dan status halal bersifat sementara. Bagi umat Islam, branding tidak dapat dipisahkan dari iman, yang menentukan bahwa semua aktivitas harus bersifat ilahi dan perasaannya akan sesuai dengan tuntunan Allah, (Alserhan, 2010). Meningkatnya minat pada merek dan pemasaran Islam karena argumen yang meyakinkan diberikan oleh ukuran pasar semata, meningkatnya kesadaran akan konsumsi Islam dan pemberdayaan konsumen Islam yang lebih besar. Selain itu, negara dan perusahaan Islam telah melihat kekuatan merek di pasar global dan menyaksikan merek konvensional pindah ke pasar Muslim. Oleh karena itu, merupakan awal yang baik bagi sarjana akademis untuk mengubah merek Islam menjadi pasar konvensional.

Dari semua pemahaman tentang istilah merek Islam, Jumani \& Siddiqui (2012) telah menyatakan sebuah merek harus memenuhi semua aspek merek untuk konsumen Muslim, karena konsumen Muslim mengkonsumsi barang atau jasa tersebut, yang memenuhi hukum dan norma Islam. Konsumen Muslim menginginkan merek yang berbicara kepada mereka (Power \& Abdullah, 2009), merek Islami atau merek Halal diciptakan sesuai dengan prinsip-prinsip Islam yang membimbing apa yang diijinkan 
tidak hanya di industri makanan tetapi juga di bidang kosmetik, farmasi, logistik, pakaian, keuangan, perhotelan dan perbankan (Minkus-McKenna, 2007). Pasar makanan halal dan sektor keuangan Islam telah meledak dalam dekade terakhir dan banyaknya produk dan layanan Islami lainnya termasuk kosmetik, real estat, hotel, fashion dan asuransi, (Alserhan, 2010a).

Tabel 1

Tipe Merek Islam (Islamic Brands)

\begin{tabular}{|c|c|c|}
\hline TIPE & PENGERTIAN & FOKUS PEMASARAN \\
\hline $\begin{array}{l}\text { Merek Islam yang benar } \\
\text { (true Islamic brands) }\end{array}$ & $\begin{array}{l}\text { Produk yang halal, diproduksi } \\
\text { di negara Islam, dan mereka } \\
\text { menargetkan konsumen } \\
\text { Muslim. Pangsa pasar utama } \\
\text { adalah konsumen muslim. }\end{array}$ & $\begin{array}{l}\text { Menekankan halal dan } \\
\text { patriotisme }\end{array}$ \\
\hline Merek Islam tradisional & $\begin{array}{l}\text { Merek yang berasal dari } \\
\text { negara Islam dan menargetkan } \\
\text { konsumen Muslim }\end{array}$ & $\begin{array}{l}\text { menekankan patriotisme } \\
\text { lebih dari halal, meskipun } \\
\text { halal tetap diasumsikan } \\
\text { ada }\end{array}$ \\
\hline Merek Islam inbound & $\begin{array}{l}\text { Merek halal yang } \\
\text { menargetkan konsumen } \\
\text { Muslim tapi berasal dari } \\
\text { negara-negara non-Islam. } \\
\text { Merek-merek ini sebagian } \\
\text { besar "diislamkan", yaitu } \\
\text { diubah menjadi merek yang } \\
\text { halal. }\end{array}$ & $\begin{array}{lcr}\text { Kualitas halal } & \text { dan } \\
\text { ternama dari } & \text { merek } \\
\text { internasional ditekankan }\end{array}$ \\
\hline Merek Islam outbound & $\begin{array}{l}\text { Merek halal yang berasal dari } \\
\text { negara-negara Islam namun } \\
\text { belum tentu menargetkan } \\
\text { konsumen Muslim. }\end{array}$ & $\begin{array}{l}\text { Kemurnian dan } \\
\text { kemanusiaan ditekankan } \\
\text { agar tidak menimbulkan } \\
\text { kepekaan religius }\end{array}$ \\
\hline
\end{tabular}

Sumber: Alserhan (2010)

Perlu dicatat bahwa mengkomersilkan Islam jauh lebih kecil kemungkinannya terjadi karena sifat dan ajaran iman Islam itu sendiri. Dalam Islam ada kondisi yang jelas dan ketat yang harus dipatuhi sebelum sebuah perusahaan bisa mendapatkan pada kendaraan pemasaran agama. Dalam Islam, merek tidak dapat sesuai dengan Syariah sampai mereka memenuhi banyak kondisi yang berkaitan dengan bahan, logistik, dampak dan niat. Hasil pemenuhan tersebut menghasilkan apa yang secara islami disebut "halal" 
atau produk sehat. Dalam hal ini, agama memainkan sebuah peran aktif dalam mentransformasikan bisnis menjadi entitas etis yang tujuannya naik di atas penjualan dan pendapatan (Alserhan, 2010).

\section{CITRA MEREK HALAL}

Citra merek seperti yang didefinisikan oleh Keller (2011) adalah Persepsi tentang merek yang tercermin dari asosiasi merek yang ada dalam memori konsumen sementara asosiasi merek adalah node informasi lainnya yang terkait dengan merek di memori dan mengandung arti merek bagi konsumen. Islam, sama seperti agama terkenal lainnya, memiliki sebuah citra. Hal ini dapat dianggap sebagai merek dengan sendirinya, dengan citra mereknya sendiri; dan seperti merek global lainnya. Meski demikian citra merek Islam dipandang berbeda oleh orang yang berbeda di tempat yang berbeda meski dari konsumen Muslim. Akademisi harus memikirkan apakah semua Muslim menganggap hal yang sama dan berperilaku sama, apakah mereka menginginkan produk dan layanan yang sama dan yang paling penting, apakah Muslim menginginkan merek konvensional atau merek Islam, (Sandikci, 2011).

Salah satu hambatan paling mendasar bagi pertumbuhan merek-merek Islam adalah mencapai brand awareness saat memasuki pasar ramai yang didominasi oleh merek Barat atau konvensional. Di sisi lain, mendidik konsumen tentang halal berarti juga merupakan tantangan bagi pemasar. Temporal (2011) telah menunjukkan bahwa dalam perspektif pemasaran Muslim ke Muslim, memiliki merek Halal yang diterima adalah penting; Tapi dari perspektif pemasaran Muslim ke non-Muslim, kualitas terbaik adalah sebuah keharusan. Merek Islam dapat memanfaatkan nilai-nilai agama untuk membangun merek daya tarik universal bagi khalayak Muslim dan non-Muslim.

Beberapa merek dengan cerdik mencampur karakteristik rasional dan emosional dari kepribadian merek mereka, sehingga merek dapat melenturkan karakter merek agar sesuai dengan audiens yang mereka hadapi. Jika situasi ini terjadi, maka akan merugikan kemurnian dan pesan merek-merek Islam. Oleh karena itu, penelitian tentang merek halal, khususnya aspek-aspek yang berkaitan dengan branding dan bisnis, masih dalam tahap awal, dan ini adalah kebutuhan akademisi untuk mencari tahu tentang merek-merek Islam, (Wilson \& Liu, 2010). Alam \& Sayuti (2011) telah menyebutkan bahwa setiap kategori 
produk menawarkan berbagai merek baik yang dinamai maupun dikenal secara lokal. Beberapa merek lokal tampaknya menangkap ceruk mereka sendiri dengan memproyeksikan diri mereka sebagai merek Islam dan juga secara tidak langsung menandakan status halal produk mereka. Ini akan menjadi religiusitas secara tidak benar dan tidak etis jika produk yang tidak sesuai dengan Syariah dicap sebagai merek Islam (Alserhan, 2010b).

\section{PASAR PRODUK HALAL}

Menurut Sandikci dan Jafari (2013) dalam beberapa tahun terakhir, Islam telah menjadi sangat terlihat baik di media, politik, maupun pasar. Di bagian pasar seperti yang terlihat akhir-akhir ini produk dengan label halal menjadi pilihan konsumen dalam keputusan pembelian barang. Kita sekarang pada titik di mana halal lebih dari sekedar permasalahan religious. Halal adalah bisnis yang besar, dari pembuatan produk halal sampai dengan perputaran uang di bank syariah.

Perusahan multinasional yang memasuki pasar halal yang luas, harus membuatnya menjadi lebih global dalam hal memperhatikan kebutuhan umat Islam sebagai segmen baru pelanggan. Perusahaan tidak akan benar-benar global kecuali mereka melayani pasar ini (Power dan Gatsiounis 2007). Misalnya, Nestlé melakukan industri halal lebih awal dibandingkan produsen lain. Kenyataannya, pelaksanaan halal - mencakup aspek pengendalian, kepastian dan manajemen untuk memastikan bahwa produk tersebut mencapai status halal dan dipertahankan melalui keluarnya - di Nestlé Malaysia pada tahun 1970an, diikuti oleh pembentukan komite halal pada tahun 1980an untuk mengawasi standar halal dari pertanian ke pabrik untuk operasi perusahaan di seluruh dunia.

Diperkirakan pasar produk halal akan terus tumbuh secara substansial. Seiring tumbuh, diperkirakan bahwa lorong di supermarket di seluruh dunia akan didedikasikan untuk produk ini, dengan cara yang sama seperti produk kosher dan produk etnik lainnya hari ini (Minkus-McKenna, 2007). Seperti industri halal dan organik, produk halal bergerak ke arus utama dan menarik bagi konsumen yang mencari produk etis berkualitas tinggi. Beberapa perusahaan yang sesuai dengan syariah mengungkapkan bahwa tidak semua pelanggan mereka beragama Islam. 


\section{KATEGORI HALAL}

Industri halal tumbuh dalam kecanggihan dan ukuran. Ini bukan lagi tentang daging saja; Ini mencakup produk dari lipstik hingga vaksin ke rekening tabungan. Sebagai ilustrasi, pada tahun 1990 Dewan Makanan dan Gizi Islam hanya memiliki 23 klien yang membayar jasa sertifikasi halal. Tahun lalu produk yang telah disertifikasi untuk 2000 perusahaan di seluruh dunia (Power dan Gatsiounis, 2007).

Secara umum, pasar halal dapat dibagi menjadi tiga kategori saling terkait; makanan, gaya hidup dan layanan.

\section{Makanan}

Kategori makanan saat ini didominasi oleh perusahaan multinasional non-Muslim seperti KFC dan Nestlé, walaupun produsen Muslim seperti merek Al Islami di Uni Emirat Arab dan Almarai di Saudia Arabia serta segudang produsen lokal kecil berkembang dengan pesat. Kurangnya merek halal Arab di pasar internasional adalah karena konsep makanan halal tidak pernah menjadi masalah di tingkat negara-negara Arab. Konsep ini dianggap biasa karena semua makanan yang dijual di pasar ini adalah halal. Pengakuan signifikansi halal tidak berevolusi sampai pasar Arab menjadi lebih terbuka terhadap perdagangan global dan dibanjiri produk makanan yang berasal dari negara-negara non-Muslim yang tidak memiliki pemahaman yang jelas tentang pentingnya konsep halal terhadap pasar muslim mereka.

\section{Gaya Hidup}

Dalam kategori gaya hidup yang juga didominasi oleh perusahaan multinasional nonMuslim, produsen kosmetik halal Islam, yaitu tanpa alkohol atau lemak hewan, secara perlahan membangun merek mereka di pasar Muslim. Perkembangan kategori produk halal yang lamban, dibandingkan dengan kategori makanan, dapat dikaitkan dengan dua faktor. Pertama, meski penting, itu sama sekali tidak memiliki urgensi yang sama dengan makanan. Kedua, baik Muslim maupun perusahaan multinasional belajar terlambat

karena halal benar-benar melampaui makanan, kegiatan sehari-hari juga dapat diislamkan dan digolongkan sebagai halal, dan oleh karena itu produk-produk terkait gaya hidup khas Islam mulai dikembangkan untuk memenuhi kebutuhan pasar ini dan pada saat bersamaan, memanfaatkan kesempatan yang diberikannya. Seperti yang dapat kita lihat di 
industri kosmetik Indonesia, beberapa tahun terakhir muncul merek kosmetik yang disertai dengan label halal misalnya Wardah dan Zoya.

\section{Layanan}

Kategori layanan meliputi keuangan, perhotelan dan logistik, antara lain. Dari jumlah tersebut, layanan keuangan halal paling maju dengan bank-bank Islam yang mengendalikan sejumlah besar uang dan tumbuh pada tingkat tahunan hampir 15 persen. Bank yang beroperasi sesuai hukum Syariah berjalan dengan baik selama krisis global karena cenderung lebih konservatif. Di perhotelan, hotel semakin banyak menjalankan jalur Islam, misalnya Noor Hotel di Bandung yang menawarkan hotel unik berkonsep islami.

\section{KLASTER HALAL}

Globalisasi pasar mengakibatkan meningkatnya adopsi model bisnis baru untuk operasi manufaktur dan logistik produk, di mana pengelolaan rantai pasokan memerlukan penggunaan model logistik baru untuk memastikan keunggulan kompetitif (Trappey et al., 2011). Untuk menjamin ketersediaan dan akses terhadap makanan halal, sebuah paradigma baru diperlukan untuk mengatur produksi dan perdagangan makanan halal dengan lebih baik melalui klaster halal. Model cluster halal didasarkan pada lima pilar, yaitu:

\section{Konsumen Muslim;}

Prinsip-prinsip Islam mengajarkan umat Islam untuk mengkonsumsi halal, larangan haram dan menghindari hal-hal yang meragukan (Al-Qaradawi, 2007). Nilai-nilai Islam ini dibentuk oleh aliran pemikiran, fatwa, dan adat istiadat Islam, oleh karena itu, menjadi pasar yang spesifik (Tieman et al., 2012). Wilson dkk. (2013) percaya bahwa sangat penting bagi merek dan pemasaran Islam untuk bergerak melampaui sekadar menaikkan bendera "Merek Islam".

2. Pendidikan dan penelitian;

Menurut Sheffi (2012), lembaga pendidikan dan penelitian merupakan mesin inovasi dan oleh karena itu penting bagi keberhasilan sebuah klaster. Untuk 
menciptakan tenaga kerja yang memadai untuk klaster halal, pendidikan kejuruan dan profesional harus tersedia. Pelatihan kejuruan penting untuk mendukung pengembangan keterampilan yang diperlukan bagi industri yang berbasis di klaster (pengadaan, produksi, logistik, penjualan, dll.) Dan menyediakan berbagai modul pelatihan tentang halal (makanan halal, logistik halal, auditor halal, dll. ).

3. Jaringan integritas halal;

Menurut IHI Alliance (2010) dan Tieman dkk. (2012), logistik halal, gudang halal, transportasi halal dan terminal halal dapat dibedakan. Layanan logistik halal harus memfasilitasi konsolidasi barang halal untuk memungkinkan aset halal yang berdedikasi (Zulfakar dkk., 2014) dan meningkatkan integrasi (Talib dkk., 2013a) di antara penyedia layanan logistik. Ada peran untuk pusat distribusi regional halal untuk memberikan konsolidasi, logistik dan logistik tambahan nilai tambah di gerbang halal regional (pelabuhan dan bandara yang sesuai dengan prinsip halal).

4. Rantai pasokan halal; dan

Rantai pasokan halal terdiri dari, produsen, distributor dan konsumen. Menurut Porter (1990), kehadiran industri pemasok yang kompetitif secara internasional di suatu negara menciptakan keuntungan di industri hilir dalam beberapa cara. UKM memainkan peran penting dalam mengembangkan kapasitas pasokan untuk cluster halal suatu negara (Shariff and Lah, 2014; Talib et al., 2013b; Siaw and Rani, 2012; Machfud et al., 2011). Karena mengamankan pasokan saat ini merupakan hambatan utama industri halal (makanan), banyak

penekanannya, dalam kelompok halal, harus diberikan pada pengembangan pemasok bahan dan aditif. Di samping akses terhadap bahan baku, kemasan merupakan pemasok penting dalam kelompok makanan agribisnis.

5. Pelaku

Pelaku dari klaster halal terdiri dari Pemerintah, Perdagangan Halal, dan Keuangan Syariah. Sheffi (2012) berpendapat bahwa peran pemerintah dalam kluster yang kuat, karena mereka adalah investasi utama di pusat transportasi, mengendalikan penggunaan lahan (untuk pertanian dan taman halal), menawarkan 
insentif untuk mendorong investasi (dalam industri makanan halal, logistik, perdagangan, keuangan Islam, pengembangan UKM), mendukung pendidikan dan menyediakan kerangka peraturan. Di sisi lain, Porter (1990) berpendapat bahwa pemerintah murni seorang influencer; baik secara positif maupun negatif, hal itu mempengaruhi kondisi faktor, persaingan, kondisi permintaan dan industri terkait dan pendukung di suatu negara.

\section{DAFTAR PUSTAKA}

Aaker, D.A. (1991), Managing Brand Equity: Capitalizing on the Value of a Brand Name, The Free Press, New York, NY.

Alam, S. S., \& Sayuti, N. M. (2011). Applying the Theory of Planned Behavior ( TPB ) In Halal Food Purchasing. International Journal of Commerce and Management, 21(1), 8-20.

Alserhan, B.A. (2010), "On Islamic branding: brands as good deeds", Journal of Islamic Marketing, Vol. 1 No. 2, pp. 101-6.

Minkus-McKenna, D . ( 2007 ) The pursuit of halal . Progressive Grocer 86 (17) : 42 .

Power, C . and Gatsiounis, I . ( 2007 ) Meeting the halal test . Forbes Asia 3 (6) : 38-40 .

Sandikci, Ö. (2011). Researching Islamic marketing: Past and future perspectives. Journal of Islamic Marketing, 2(3), 246-258.

Temporal, P (2011). Islamic Branding and Marketing, Creating a Global Islamic Business: John Wiley \& Sons (Asia) Pte. Ltd.

Wilson, A \& Liu, J (2011).The Challenges of Islamic branding: Navigating Emotions and Halal: Journal of Islamic Marketing, Emerald Group Publishing Limited.

Wilson, J.A.J. (2012), "The new wave of transformational Islamic marketing: reflections and definitions", Journal of Islamic Marketing, Vol. 3 No. 1, pp. 5-11. 